Academic Platform Journal of Engineering and Science

journal homepage: http://apjes.com/

\title{
Engelli Karıştırmalı Tanklarda Karıştırıcı Hızı Değişiminin Pickering Emülsiyonlarının Damlacık Boyut Dağılımı Üzerine Etkisi
}

\author{
${ }^{1}$ Usman Kayode Abdulrasaq, *2Inci Ayranci \\ ${ }^{1}$ Kimya Mühendisliği Bölümü, Orta Doğu Teknik Üniversitesi, usman.abdulrasaq@metu.edu.tr, \\ ${ }^{2}$ Kimya Mühendisliği Bölümü, Orta Doğu Teknik Üniversitesi, ayranci@metu.edu.tr (iD \\ Research Paper \\ Arrival Date: 21.03.2019 \\ Accepted Date: 16.09.2019
}

$\ddot{O} z$

Pickering emülsiyonları, katı parçacıklar ile stabilize edilmiş emülsiyonlardır. Sürfaktan bazlı emülsiyonlara potansiyel bir alternatiftirler. Pickering emülsiyonunun kararlığı, dağılmış faz damlacıklarının büyüklüğü ile ilişkilidir. Küçük damlacıklar daha kararlıdır. Pickering emülsiyonlarının kararlığı, emülsiyonları üretmek için kullanılan partiküllerin özelliklerine ve üretim işleminde sağlanan karıştırmaya bağlıdır. Bu araştırma, karıştırıcı hızının değişsiminin, karıştırılmalı tankta üretilen Pickering emülsiyonlarının damlacık boyutuna etkisini incelemektedir. Silikon yağı saf su içinde dağıtılmış ve su içinde yağ türü emülsiyonlar oluşturmak için hidrofilik cam parçacıklarla stabilize edilmiştir. İki farklı boyutta farklı makaslama kapasitesine sahip iki farklı karıştırıcı kullanılmıştır: Rushton türbini ve eğimli bıçaklı türbin. Elde edilen damlacık boyut dağılımı Malvern Mastersizer 3000® ile belirlenmiştir. Yeterli akış sağlayabilen karıştırıcılar için, karıştırıcı hızının arttırılmasının emülsiyonun damlacık boyutunu azalttığı görülmüştür. Hızı azaltmanın, mevcut stabilize bir emülsiyonun damlacık boyutunu arttırdığı görülmüştür. Emülsiyon oluşumunda bir hız histerezisi gözlenmiştir. Karıştırma süresi analizi, damlacıkların tankın bazı bölgelerinde kalma süresinin, artan hızla damlacık büyüklüğünün azalmasının nedeni olduğunu doğrulamıştır.

Anahtar Kelimeler: Pickering emülsiyonu, sıvı-sıvı karıştırma, karıştırmalı tank, damlacık birleşimi, emülsifikasyon

\section{The Effect of the Change of Impeller Speed on the Droplet Size Distribution of Pickering Emulsions in a Baffled Stirred Tank}

\author{
${ }^{1}$ Usman Kayode Abdulrasaq, *2Inci Ayranci \\ ${ }^{1}$ Department of Chemical Engineering, Middle East Technical Unviersity, usman.abdulrasaq@ metu.edu.tr, \\ ${ }^{2}$ Department of Chemical Engineering, Middle East Technical Unviersity, ayranci@ metu.edu.tr
}

\begin{abstract}
Pickering emulsions are emulsions stabilized by solid particles. They are a potential alternative to surfactant-based emulsions. The stability of a Pickering emulsion is related to the size of the dispersed phase droplets. Smaller droplets are more stable. The stability of Pickering emulsions depends on the properties of the particles used to produce the emulsions and the agitation provided in the production process. This paper investigates the effect of the change of impeller speed on the droplet size of Pickering emulsions produced in a baffled stirred tank. Silicon oil was dispersed into distilled water and stabilized with hydrophilic glass beads to form oil in water Pickering emulsions. Two different impellers with different shearing capacities at two different sizes were used: the Rushton turbine and the pitched blade turbine. The resulting droplet size distribution was determined with Malvern Mastersizer 3000®. For impellers with adequate flow, increasing the impeller speed decreases the droplet size of the emulsion. Decreasing the speed increases the droplet size of the emulsion. A speed hysteresis was observed in the emulsion formation. Mixing time analysis confirmed that the residence time of droplets in parts of the tank was the reason of the droplet size decrease with increasing speed.
\end{abstract}

Keywords: Pickering emulsions, liquid-liquid mixing, stirred tank, droplet coalescence, emulsification 


\section{INTRODUCTION}

An emulsion is defined as two immiscible liquids in which drops of one phase (the dispersed phase) are encapsulated or enclosed within another phase (the continuous phase). Emulsions and emulsification processes are commonly encountered in many fields such as the cosmetics, pharmaceutical, paints, food processing, oil and petrochemical industries. There are two basic types of emulsions: oil-in-water $(\mathrm{O} / \mathrm{W})$ emulsions and water-in-oil (W/O) emulsions. In $\mathrm{O} / \mathrm{W}$ emulsions, the oil drops are dispersed and encapsulated within the water phase. In W/O emulsions, water is dispersed within the oil phase [1]. For the formation of a stable emulsion, three conditions must be satisfied [1]: a) The two liquids must be immiscible or mutually insoluble in each other b) Sufficient agitation must be applied to disperse one liquid into the other c) An emulsifying agent must be present.

The emulsifier plays an important role in the formation of emulsions. It lowers the interfacial energy between the phases. The emulsifier also adsorbs at the oil/water interface and prevents the coalescence of newly formed droplets due to electrostatic and steric repulsive forces. It stabilizes the emulsion and controls the type of emulsion to be formed. Conventionally, chemical surfactants or amphiphilic polymers are used to stabilize emulsions. However, there has been an increasing interest in the use of solid particles to produce highly stable emulsions. Pioneering work by Pickering (1907) highlighted the possibility of solid particles adsorbing to an oil/water interface to form emulsions [2]. Such emulsions are hence named Pickering emulsions. Binks (2002) further highlighted that particles could produce even more stable emulsions than surfactants [3]. Pickering emulsions are also potentially less costly and more environmentally friendly alternatives to surfactant-based emulsions.

Numerous studies have highlighted critical properties of Pickering emulsions stabilized by different types of particles $[3,4,5,6,7,8,9]$. Most of these studies attributed the formation of Pickering emulsions to the formation of a steric barrier around the dispersed phase droplets. The particle barrier network formation is summarized in three steps. 1) Particle approaching the interphase 2) Adsorption and entrapment of the particles at the interface 3) Particle network formation and stabilization of the emulsion droplet by the adsorbed particles [7].

The properties of the particles and the hydrodynamic agitation come together to form the final drop size distribution. The particles adsorb onto the generated interface and a 'limited coalescence phenomenon' described by Arditty et al. (2003) occurs [8]. The phenomenon assumes that the droplets formed will coalesce until they reach a coverage limit specified by the coverage potential and the interface generated.
For Pickering emulsion formation in a stirred tank, the breakup of the dispersed phase droplets and the suspension of the particles in the system are important. The flow produced by the impeller affects the distribution of the particles and drops throughout the tank. Droplet breakup occurs predominantly in areas around the impeller because of the intense turbulence and high shear generated in this area [10]. Particles are also able to adsorb onto the newly generated interfaces in these zones. Away from the impeller, coalescence occurs as a result of the lower turbulence and shear [11]. The drops are able to remain in contact long enough for them to coalesce. Baffles prevent vortex formation and provide axial motion. When the coverage potential is constant and sufficient in a Pickering emulsion system, the resulting droplet size distribution in the stirred tank is dependent on the agitation provided by the impeller. This can be controlled by changing the impeller rotational speed.

In this paper, the emulsion system was concentrated with a high dispersed phase concentration and the particle coverage is set constant. It is aimed to investigate how the change of impeller speed over time affects the droplet size of Pickering emulsions. The speeds were increased and decreased during emulsification to check for speed hysteresis. Two different impeller types, a pitched blade turbine (PBT) and a Rushton turbine (RT) at two sizes - T/2 and T/3 were used for this investigation.

Makale, bilimsel bir dille, farklı disiplinlerdeki ispata dayalı bilgiler ve mantıksal tartışmaların birleştirilmesi ile oluşan fikirleri içeren ve makalenin temel amaç ve yaklaşımlarını ifade eden bir giriş bölümü ile başlamalıdır. Bu bölüm tüm okuyucular dikkate alınarak yazılmalıdır. Teknik terimler, semboller ve kısaltmalar makalede ilk kullanıldıklarında tanımlanmalidir [1].

\section{MATERIALS AND METHODS}

\subsection{Materials}

Distilled water was used as the continuous phase and $100 \mathrm{cSt}$ silicon oil (XIAMETER $®$ PMX-200, Dow Corning) was used as the dispersed phase. Hydrophilic glass beads (Sovitec Microperl) with an average diameter (d50) of $20 \mu \mathrm{m}$ were used as the stabilizing particles. An oil to water ratio of $30 \%(\mathrm{v} / \mathrm{v})$ was used in the experiments with a $48 \%(\mathrm{w} / \mathrm{w})$ particle-to-oil ratio. For the mixing time experiments, Bromocresol Purple (Sigma Aldrich) was used as the indicator, 10M hydrochloric acid (Merck, ACS grade) as the acid and 10M sodium hydroxide (Merck) as the base.

\subsection{Experimental Method}

\subsubsection{Tank setup}

A $9.9 \mathrm{~cm}$ diameter (T) 1L glass beaker was used as the tank as shown in Figure 1. The tank was fully baffled to prevent vortex formation and to ensure maximum mixing. The liquid 
height $(\mathrm{H})$ was set to be equal to the tank diameter $(\mathrm{T})$. Two impellers were used to generate different flow patterns: a Rushton turbine (RT) for radial flow pattern and a downpumping $45^{\circ}$ Pitched Blade Turbine (PBT) for mixed flow pattern.

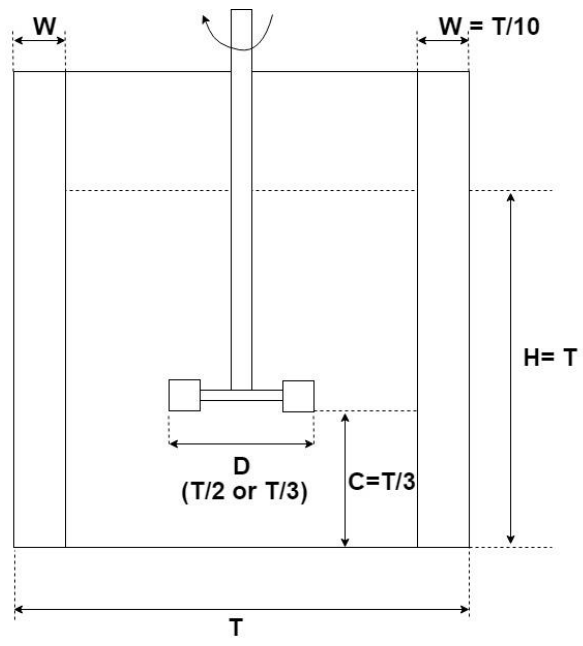

Figure 1: Stirred tank configuration

\subsubsection{Emulsification procedure}

A known amount of solid glass beads (100 g, 48\% (w/w) particle-to-oil ratio) was added into the tank. This amount of particles was chosen so that there would be excess particles in the system and the final drop sizes would be controlled by the interface generated rather than the coverage potential. Then, the impeller position was set and water was added. The particle/water mixture was stirred for 10 minutes in order to wet the particles and break up aggregates. For the two impeller sizes fixed speeds, lower than the emulsification speeds, were chosen to pre-disperse the particle/water mixture. Silicon oil was then added in a single batch and the speed was increased to the desired emulsification speed.

During emulsification, for every impeller, three different impeller speeds were used: lowest, middle and highest speed. Each speed was applied for one hour starting from the lowest speed. At the end of one hour a sample was taken and the speed was increased. Once the highest speed was applied, the speed was decreased hourly to the middle speed and then to the lowest speed in order to study the coalescence behavior. Each experiment lasted a total of 5 hours. Samples were taken from the tank at a position halfway between the impeller and the liquid surface in the axial direction and shaft and tank wall in the radial direction every hour while the impeller is rotating.

The emulsification speeds were selected to ensure the suspension of all particles with minimum air entrainment and complete entrainment of the oil phase for both impeller types. These selected speeds are given in Table 1 . The lowest speeds were selected such that they were above the just drawn down speed $\left(\mathrm{N}_{\mathrm{JD}}\right)$ of the system. $\mathrm{N}_{\mathrm{JD}}$ is the speed at which the dispersed phase is completely drawn into the continuous phase [12]. Therefore, the different impellers had different lowest speeds. In selecting the highest speeds, the air entrainment speed $\left(\mathrm{N}_{\mathrm{E}}\right)$ was considered. $\mathrm{N}_{\mathrm{E}}$ is the speed at which a significant amount of air bubbles enters and remain in the tank volume. The method implemented to determine these speeds was detailed by Bhattacharya et al. (2007) [13]. In this method the air bubbles entering the tank volume are visually observed. Air entrainment cannot be completely eliminated during emulsification, but it was observed that at impeller speeds slightly above $\mathrm{N}_{\mathrm{E}}$ the drops were not affected by the small presence of the air bubbles. The presence of air during pre-mixing was more problematic; therefore, the pre-dispersion speeds were selected below $\mathrm{N}_{\mathrm{E}}$ for all cases.

\subsubsection{Droplet measurement and analysis}

To measure the drop size obtained in a particular experiment, a sample was taken from the tank and stored in a vial for at least 2 hours. This was done to allow the excess particles to settle out at the bottom of the vial so the measured sample does not contain particles. The drops were then analyzed in a Malvern Mastersizer 3000® device. This equipment is based on the principles of static light scattering. The device records the light scattered by the droplets or particles in the samples and returns its corresponding size distribution. Each sample was analyzed at least twice. For each analysis, the device was set to perform 5 measurements. The averages of all measurements were calculated and the volume averaged diameter $\left(\mathrm{d}_{43}\right)$ was reported. The $\mathrm{d}_{43}$ is the most representative diameter obtained by light scattering techniques and the droplet size results are not significantly affected by the excess particles in the system [14].

\subsubsection{Mixing time analysis}

Mixing time is the time taken for a stirred tank to achieve a certain degree of homogeneity. A novel procedure detailed by Cabaret et al. (2007) was implemented to determine the macromixing time of the configurations tested. This procedure consists of two parts. The first part is video recording a decolorization process in the tank using a fast acid-base indicator reaction. An acid-base ratio greater than 2 was used to obtain macromixing, as recommended by Cabaret et al. (2007) [15]. Then, an image analysis technique was implemented on the recorded videos to obtain a mixing curve. The details of each part are given below.

The color change in the tank was recorded with a Canon EOS $100 \mathrm{~d}(25 \mathrm{fps})$ camera. A solution of bromocresol purple $(0.08 \% \mathrm{w} / \mathrm{w}$ in water) was used as the indicator. An injection sample was prepared by mixing a sample of the tank mixture with $2 \mathrm{ml}$ of $10 \mathrm{M} \mathrm{HCl}$. This is for the injection sample to have a density close to density of the emulsion in the tank so that a reproducible mixing curve can be obtained. The injection sample volume was set to be $0.5 \%$ of the total tank volume. At the beginning of the experiment, $1 \mathrm{ml}$ aqueous $10 \mathrm{M} \mathrm{NaOH}$ was added to the tank mixture. $20 \mathrm{ml}$ of the bromocresol purple solution was added to color the mixture purple. When a steady hydrodynamic state was reached in 
the tank, the camera was turned on. The acidic injection sample was added and the color change was recorded. For reproducibility purposes, the acid was always added rapidly at the same location on the tank surface. Since it is easier to follow the change of darker colors to lighter colors, the change of the tank volume from purple (basic) to yellow (acidic) was followed.

Table 1. Emulsification speeds

\begin{tabular}{|l|l|l|l|l|l|c|c|}
\hline Impeller & $\begin{array}{l}\text { Pre-dispersed } \\
\text { speed (rpm) }\end{array}$ & $\begin{array}{l}1^{\text {st }} \\
(\mathrm{rpm})\end{array}$ & $\begin{array}{l}2^{\text {nd }} \text { hour speed } \\
(\mathrm{rpm})\end{array}$ & $\begin{array}{l}3^{\text {rd }} \\
\text { speed hour } \\
(\mathrm{rpm})\end{array}$ & $\begin{array}{l}4^{\text {th }} \\
\text { speed } \\
(\mathrm{rpm})\end{array}$ & $\begin{array}{l}5^{\text {th }} \\
\text { speed } \\
(\mathrm{rpm})\end{array}$ \\
\hline RT T/2 & 600 & 658 & 878 & 1082 & 878 & 658 \\
\hline RT T/3 & 1100 & 1146 & 1528 & 1980 & 1528 & 1146 \\
\hline PBT T/2 & 600 & 658 & 1082 & 1500 & 1082 & 658 \\
\hline PBT T/3 & 1200 & 1485 & 1721 & 1980 & 1721 & 1485 \\
\hline
\end{tabular}

The video was split into frames using VLC software. Each frame was converted to a portable pixel map (ppm) format and was represented by a matrix of pixels which can be separated into the red, green and blue (RGB) components. For each pixel, an individual threshold on an RGB component is defined in order to separate an 'unmixed' pixel from a 'mixed' one. For bromocresol purple, it was reported by Cabaret et al. (2007) that the green component should be followed and a threshold value ratio of $50 \%$ should be used [15]. Since the green component is followed, a pixel will be considered mixed as soon as its green component is greater than the threshold value. For each image sampled from the video, the number of mixed pixels $\left(\mathrm{N}_{\text {mixed }}\right)$ was counted and then the ratio of $\mathrm{N}_{\text {mixed }} / \mathrm{N}_{\text {total }}$ over time was plotted to obtain a mixing curve, where $\mathrm{N}_{\text {total }}$ is the total number of pixels. This ratio represents the 'mixedness' of the system. 95\% was chosen as sufficient homogeneity for the system. For each experiment, a mixing curve was obtained and the time it took to obtain $95 \%$ 'mixedness' was observed.

\section{RESULTS AND DISCUSSION}

The results of experiments carried out for the different impeller types and sizes are discussed in this section. The effect the change of impeller speed on the droplet size is discussed in terms of the trend of the average droplet sizes at each speed and the distribution curve of the evolved droplets at each speed. A mixing time analysis was then used to corroborate the results.

\subsection{Effect of the change of impeller speed on droplet size and droplet size distribution}

Figure 2, Figure 3, Figure 4 and Figure 5 show the transient trend followed by the droplet sizes with the change in speed for the T/2 RT, T/3 RT, T/2 PBT and T/3 PBT impellers respectively. For all cases, as the speed increases every hour, the droplet size decreases. Then on the decreasing path, after every hour, the droplet size increases. This is the general trend observed by the impellers in this study except the PBT T/3 impeller. For an impeller at a particular speed, a certain range of droplet size is observed regardless of the emulsification time and speed hysteresis is observed. The evolution of droplet size by varying the impeller speed is different on the increasing and decreasing speed path even though the general trend of decreasing and increasing droplet size is the same. This is referred to as speed hysteresis.

Stirring has two effects: providing shear to elongate and break droplets, and providing inertia to gather the droplets and help them coalesce [16]. Increased speed should favor droplet break-up over droplet coalescence because of the increase in shear and energy dissipated. The decrease of droplet size with increasing impeller speed and emulsification time is expected because as the speed increases, droplet break-up increases. Therefore, there is more interface generated for the particles to adsorb onto and stabilize the emulsion. As the speed decreases, the droplet coalescence increases because stirring then triggers inertial forces to gather the droplets and help coalescence. The relatively lower shear and circulation generated when the speed is decreased can also cause detachment of the particles from the interface. The particles are detached when the droplets are broken and are unable to adsorb back onto the surface at the same rate as when there was a higher shear and circulation. Since the droplets are gathered and are not fully covered by the particles, coalescence is encouraged.

For the RT T/2 impeller, in Figure 2, there is not much difference between the droplet sizes produced at the same speeds on the increasing and decreasing speed paths. The droplet sizes of the $1^{\text {st }}$ and $5^{\text {th }}$ hour samples are within $7 \%$ of each other and the droplet sizes of the $2^{\text {nd }}$ and $4^{\text {th }}$ hour samples are within $3 \%$ of each other. Very little hysteresis is observed with this impeller. In a smaller size RT impeller, the impeller shear zone size is decreased. A decrease in the shear zone may favor coalescence. In Figure 3, a wider difference in droplet sizes is observed at the lowest speed. The droplet sizes of the $1^{\text {st }}$ and $5^{\text {th }}$ hour samples are within 
$21 \%$ from each other. The droplet size at the $5^{\text {th }}$ hour is significantly smaller than at the $1^{\text {st }}$ hour. The droplets could not coalesce enough to reach the droplet size of the $1^{\text {st }}$ hour. This is because ultimately, the emulsification had been going on much longer at the $5^{\text {th }}$ hour than at the $1^{\text {st }}$ hour. This emulsification time played a more significant role in the droplet size evolution for the RT T/3 impeller than it did for the RT T/2 impeller.

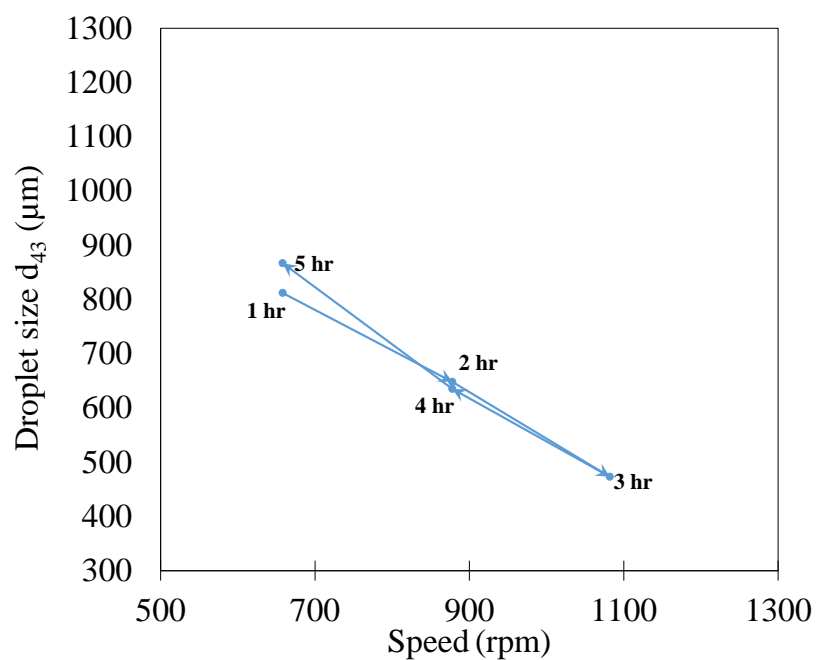

Figure 2. Effect of $T / 2$ Rushton turbine impeller speed on drop size

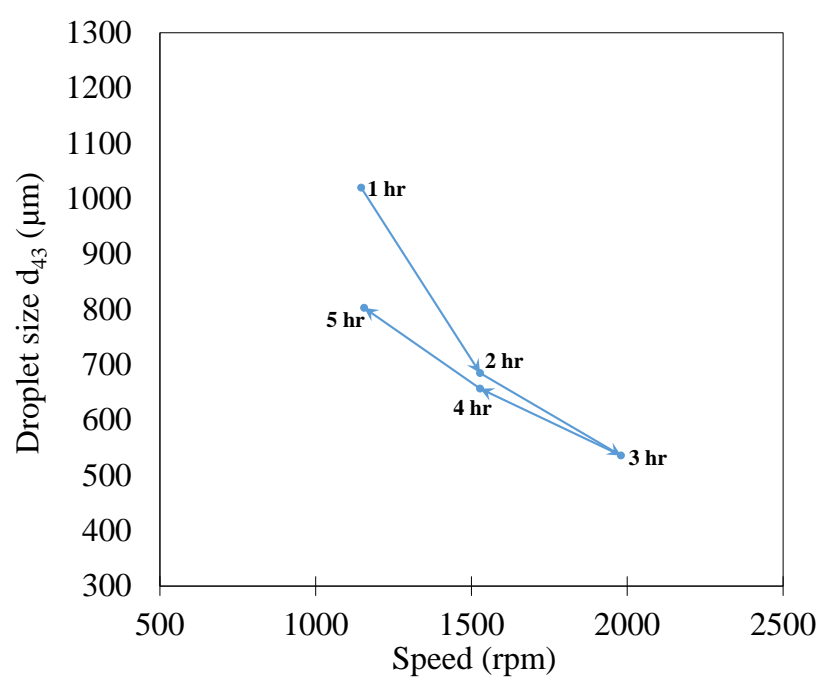

Figure 3. Effect of T/3 Rushton turbine impeller speed on droplet size

The PBT impeller is a low shear impeller compared to the RT impeller. The PBT T/2 impeller was used to see how the effect of the impeller speed on the droplet size would be affected by the change in shearing capacity. According to Figure 4, a similar trend is observed with the RT impellers: as the speed increases every hour the droplet size decreases and then after decreasing every hour the drop size increases. At the same speeds, the droplet sizes of the $1^{\text {st }}$ and $5^{\text {th }}$ hour samples are within $31 \%$ of each other and the droplet sizes of the $2^{\text {nd }}$ and $4^{\text {th }}$ hour samples are within $8 \%$ of each other. The droplet size at the $5^{\text {th }}$ hour is significantly larger than at the $1^{\text {st }}$ hour. This shows the effect of the low shearing of the impeller because in this case coalescence is encouraged. As a result of the impeller geometry and low shearing capacity, the droplets experience inertia to gather them and help coalescence at low speeds. The longer emulsification time does not have an important role this time, due to the lower shear capacity of the PBT impeller throughout emulsification.

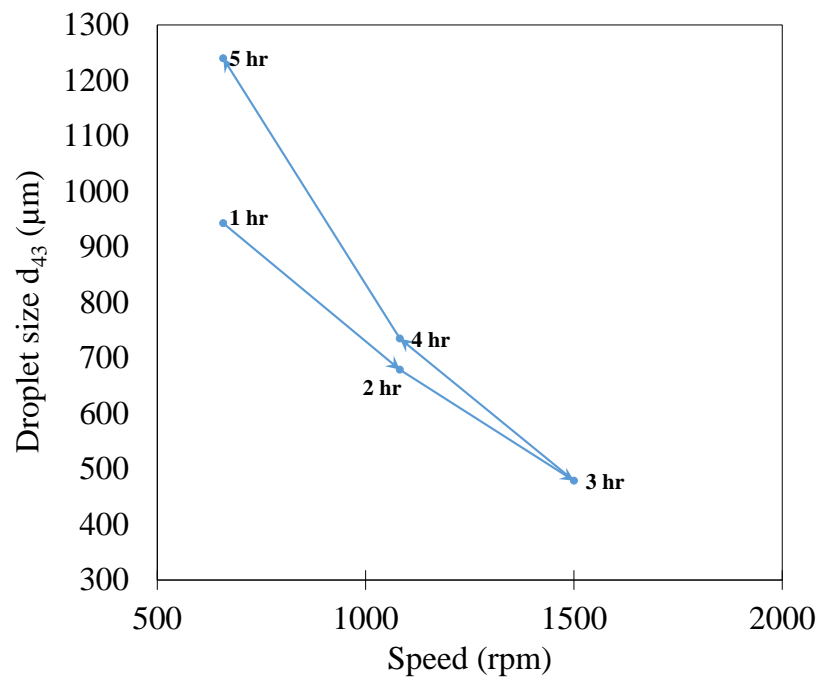

Figure 4. Effect of $T / 2$ Pitched blade turbine impeller speed on droplet size

A smaller size PBT impeller was also investigated. As seen in Figure 5, the PBT T/3 impeller shows a different trend than the other impellers. A mixed increase and decrease trend on the droplet size is observed when increasing the speed. However, when decreasing the speed, a corresponding increasing and decreasing trend is still observed. At the same speeds, the droplet sizes of the $1^{\text {st }}$ and $5^{\text {th }}$ hour samples are within $11 \%$ of each other and the droplet sizes of the $2^{\text {nd }}$ and $4^{\text {th }}$ hour samples are within $4 \%$ of each other. The reason for this outlying trend is not fully understood, but it could be a result of the flow generated by the impeller. The flow of the PBT T/3 is observed to have poor circulation and dead zones around the top of the liquid level and baffle areas. The dead zones are regions where there is no fluid movement and therefore no droplet movement is observed around that area. However, similar to other impellers, a certain path is followed in the droplet evolution with change in speed regardless of the emulsification time. It also produces larger droplets at the lower speeds as a result of its low shearing capacity.

Figure 6 shows the distribution curves obtained by the RT $\mathrm{T} / 2$ impeller at the same speed in corresponding hours. The span indicates the width of the distributions. At the lowest speed, $658 \mathrm{rpm}$, Figure 6 a shows that the $5^{\text {th }}$ hour curve has a wider distribution than the $1^{\text {st }}$ hour curve. This shows the difference in how the droplets were evolved. At the $1^{\text {st }}$ hour the droplet size was evolved predominantly through droplet break-up, therefore they have a narrower distribution. At the $5^{\text {th }}$ hour the droplets were evolved predominantly via droplet coalescence since the speed was decreased from a higher 
speed at the $5^{\text {th }}$ hour. Since shear is still applied, some droplet break-up still occurs. This mix of activities lead to the $5^{\text {th }}$ hour droplets having a wider distribution even though it has a similar average size as the $1^{\text {st }}$ hour droplets. Figure $6 \mathrm{~b}$ shows curves of the intermediate speed, $878 \mathrm{rpm}$. The curves of the $2^{\text {nd }}$ and $4^{\text {th }}$ hour have relatively closer spans than the curves in Figure 6a. This shows that at the intermediate speeds droplet breakup and coalescence occur at similar rates as when the speed was increased to it and when the speed was decreased to it.

Figure 7, Figure 8, and Figure 9 show the width of distributions of the other impellers at corresponding speeds. Similar patterns are observed as with the RT T/2 impeller. The $5^{\text {th }}$ hour curves have wider distributions than the $1^{\text {st }}$ hour curve and the $2^{\text {nd }}$ hour and $4^{\text {th }}$ hour curves are close to each other. The same mechanism described for the RT T/2 impeller occurs in the formation of droplets when the speed is increased and when the speed is decreased.

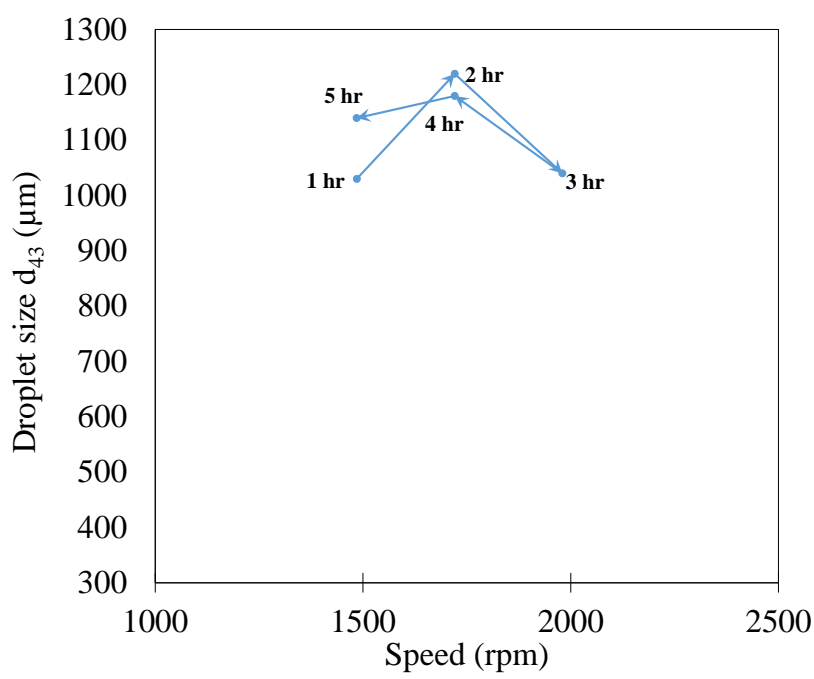

Figure 5. Effect of T/3 Pitched blade turbine impeller speed on droplet size

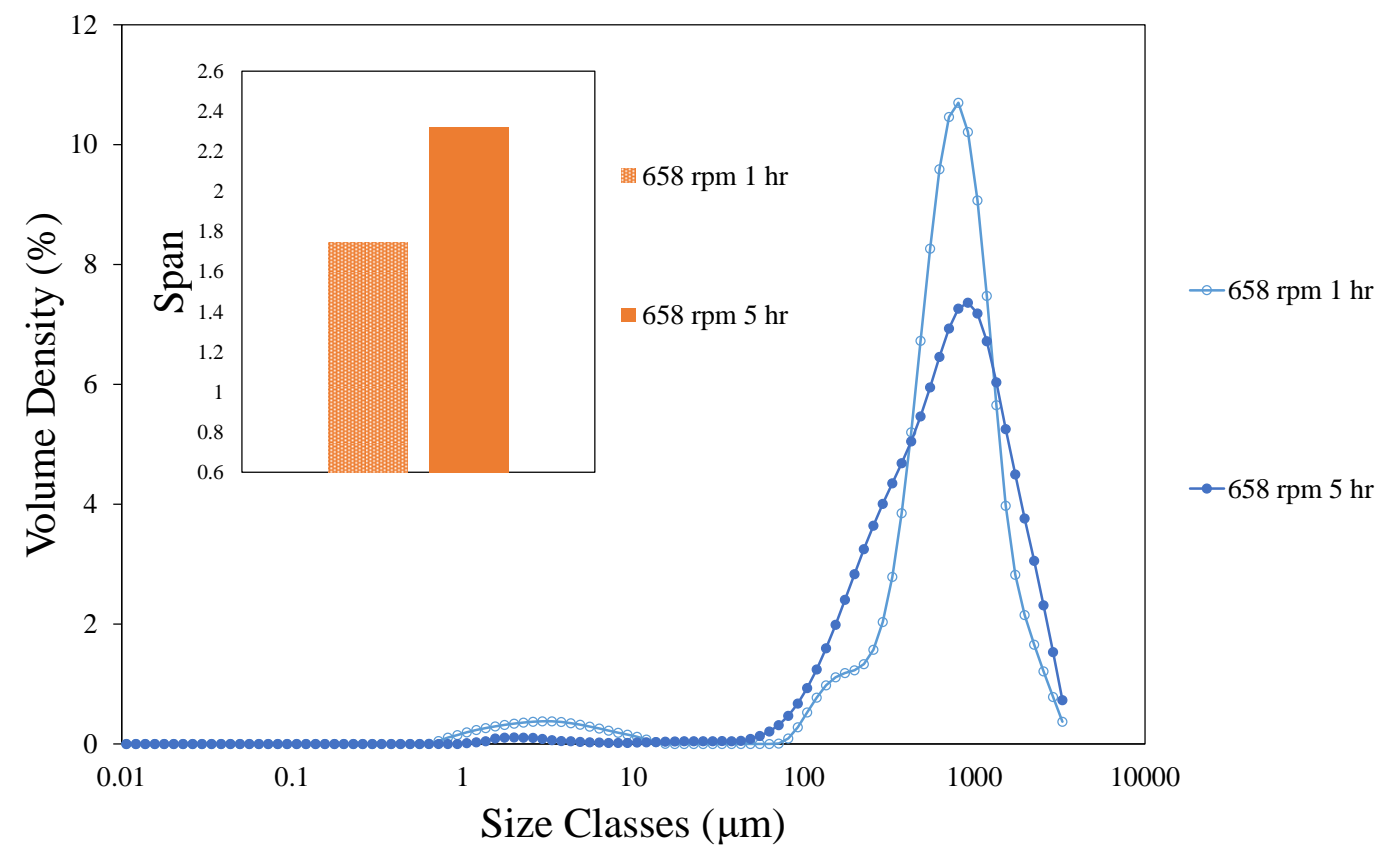

a. 


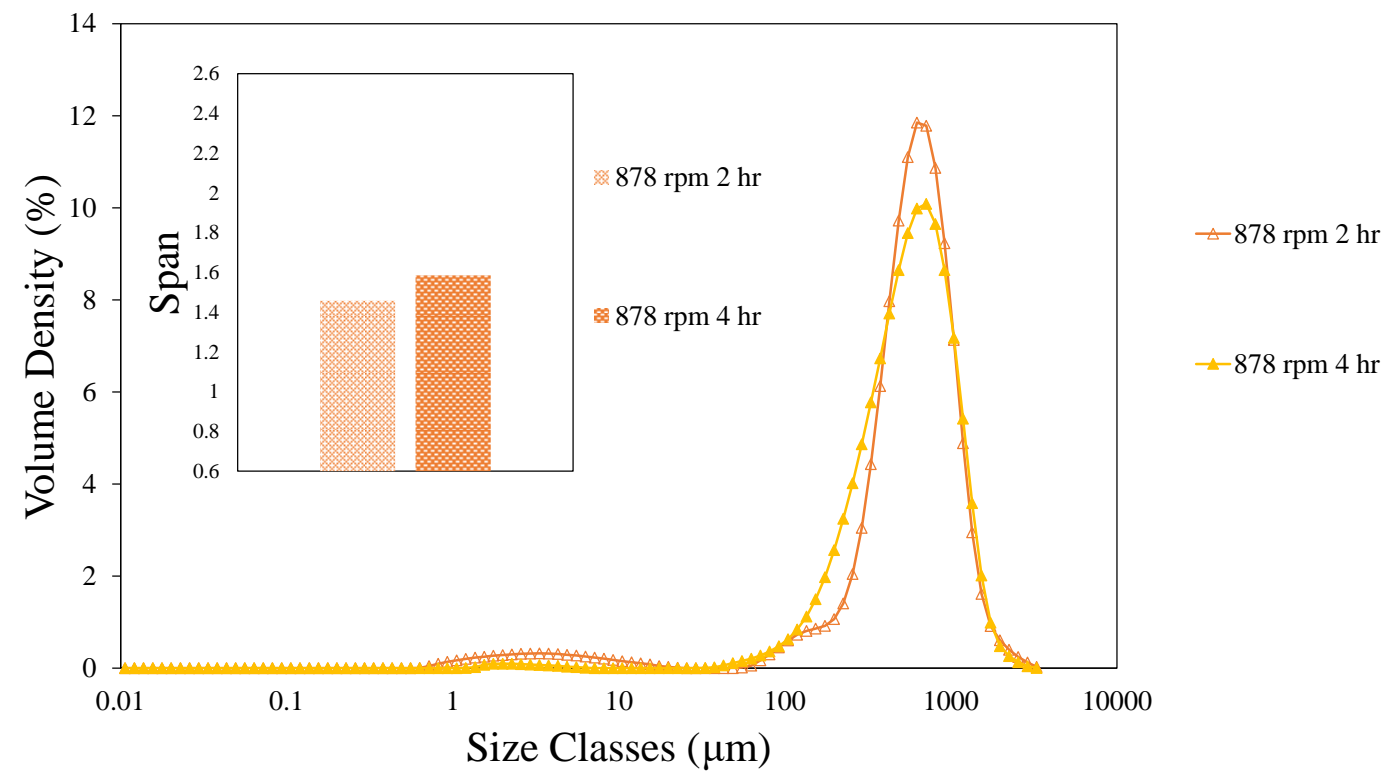

b.

Figure 6. Droplet size distribution for RT T/2 a. $658 \mathrm{rpm} \mathrm{b.} 878 \mathrm{rpm}$

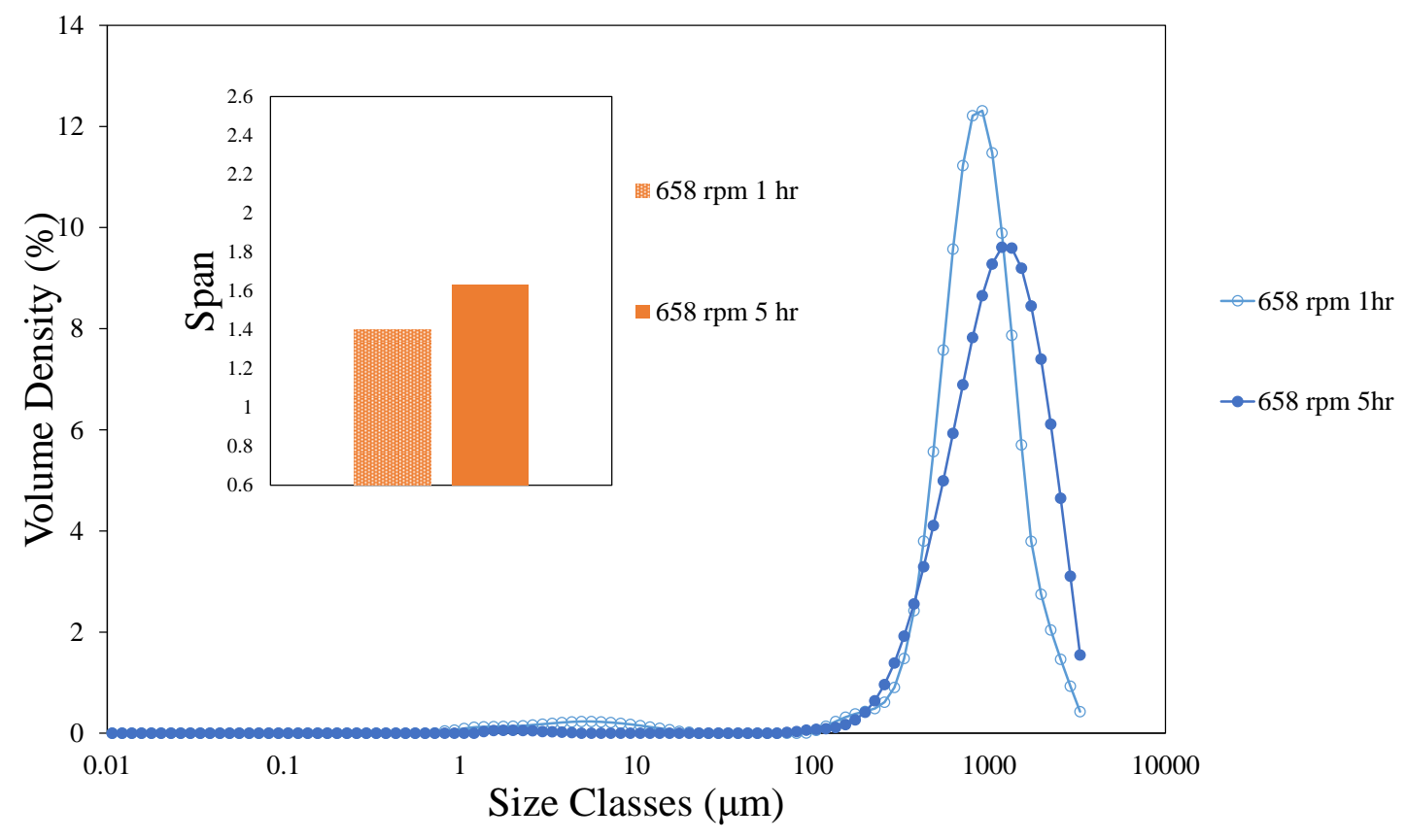

a. 


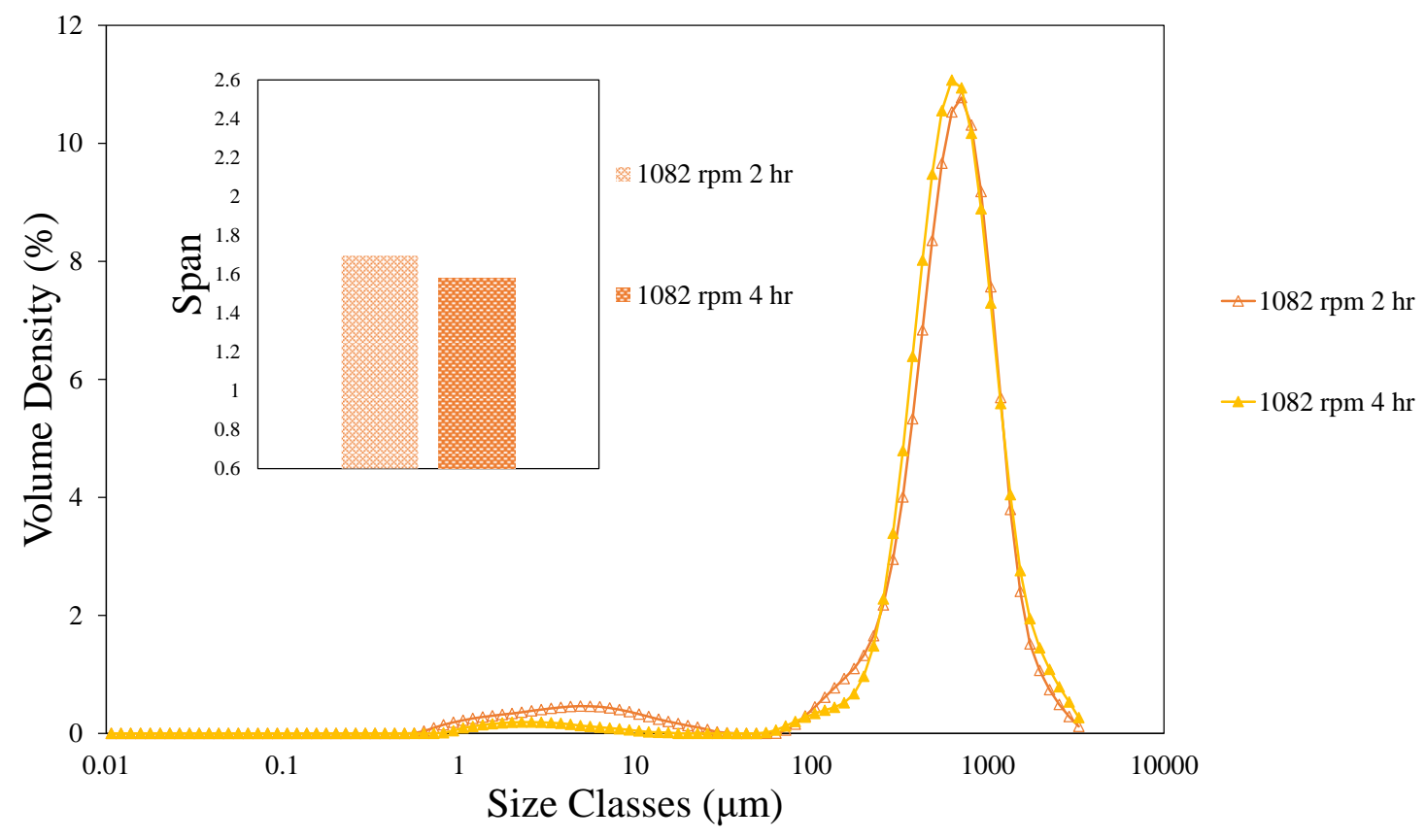

b.

Figure 7. Droplet size distribution for PBT T/2 a. $658 \mathrm{rpm}$ b. $1082 \mathrm{rpm}$

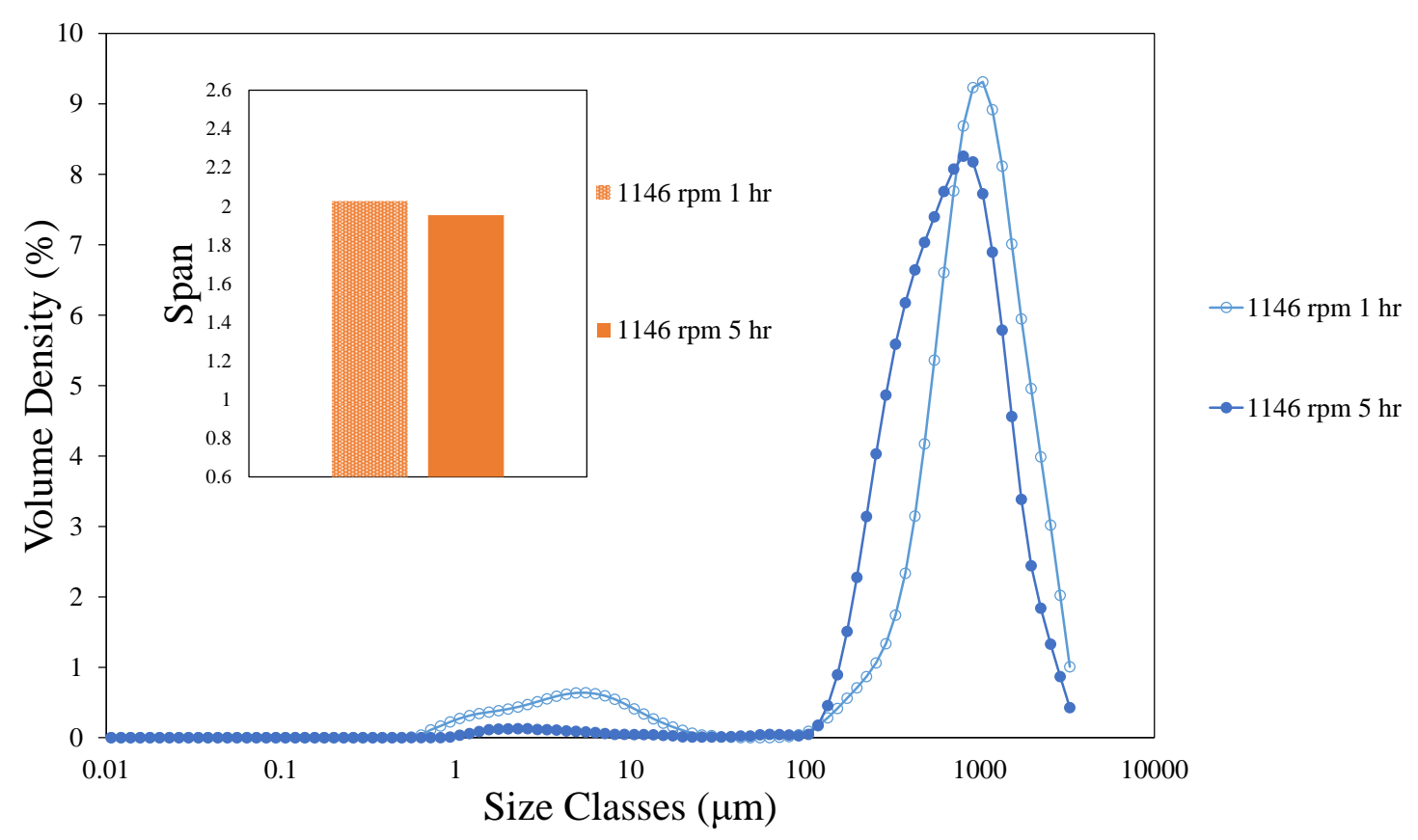

a. 


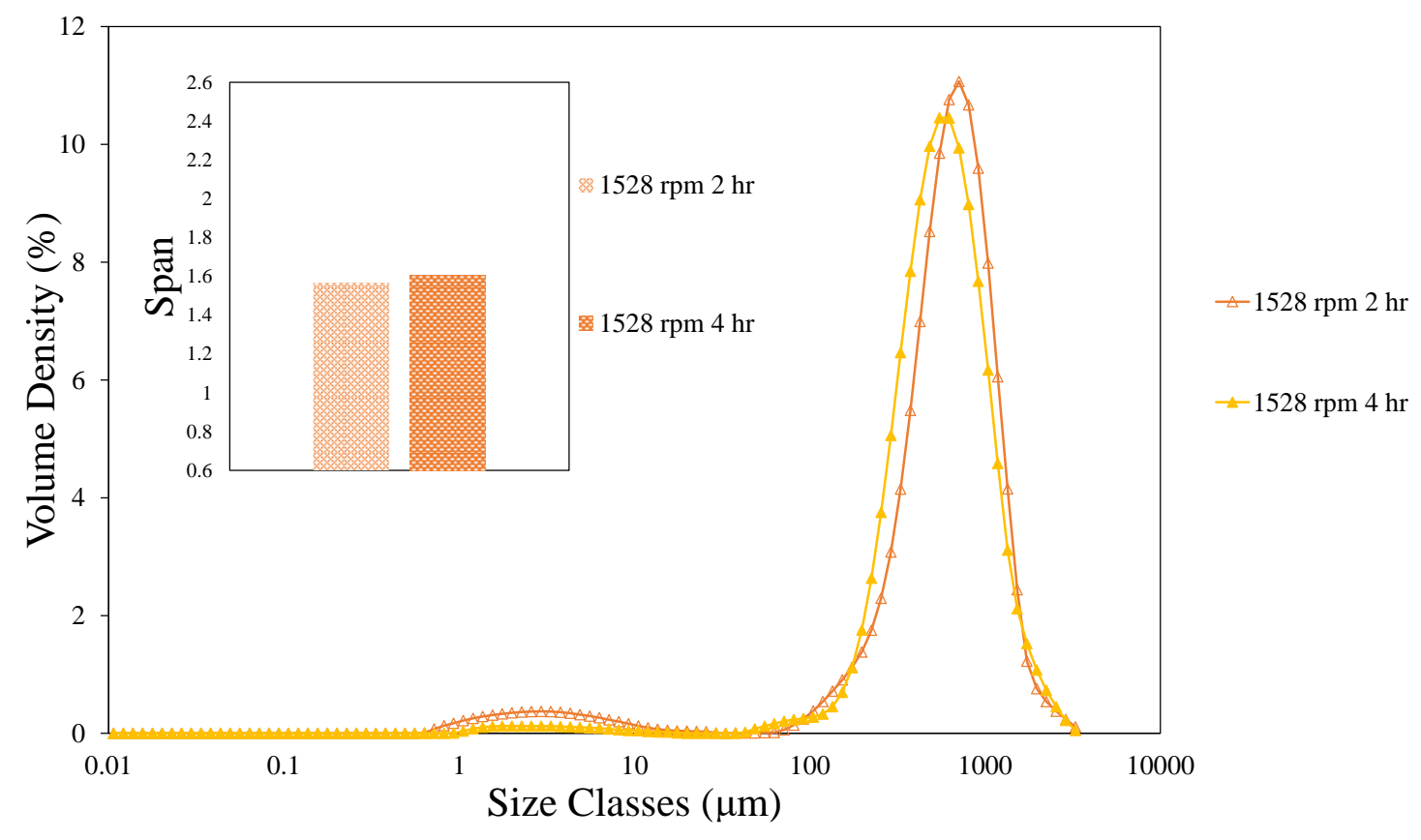

b.

Figure 8. Droplet size distribution for RT T/3 a. $1146 \mathrm{rpm}$ b. $1528 \mathrm{rpm}$

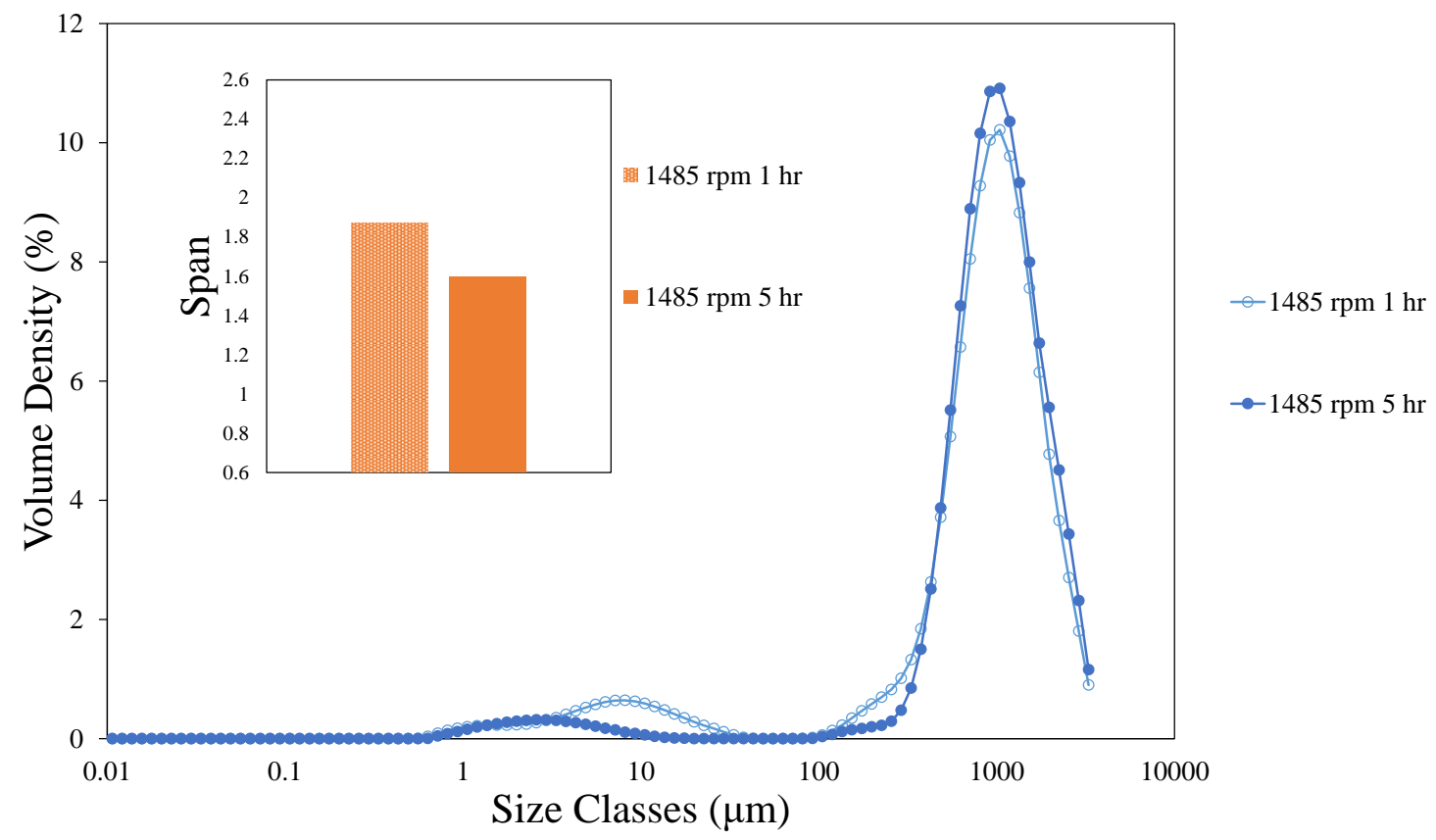

a. 


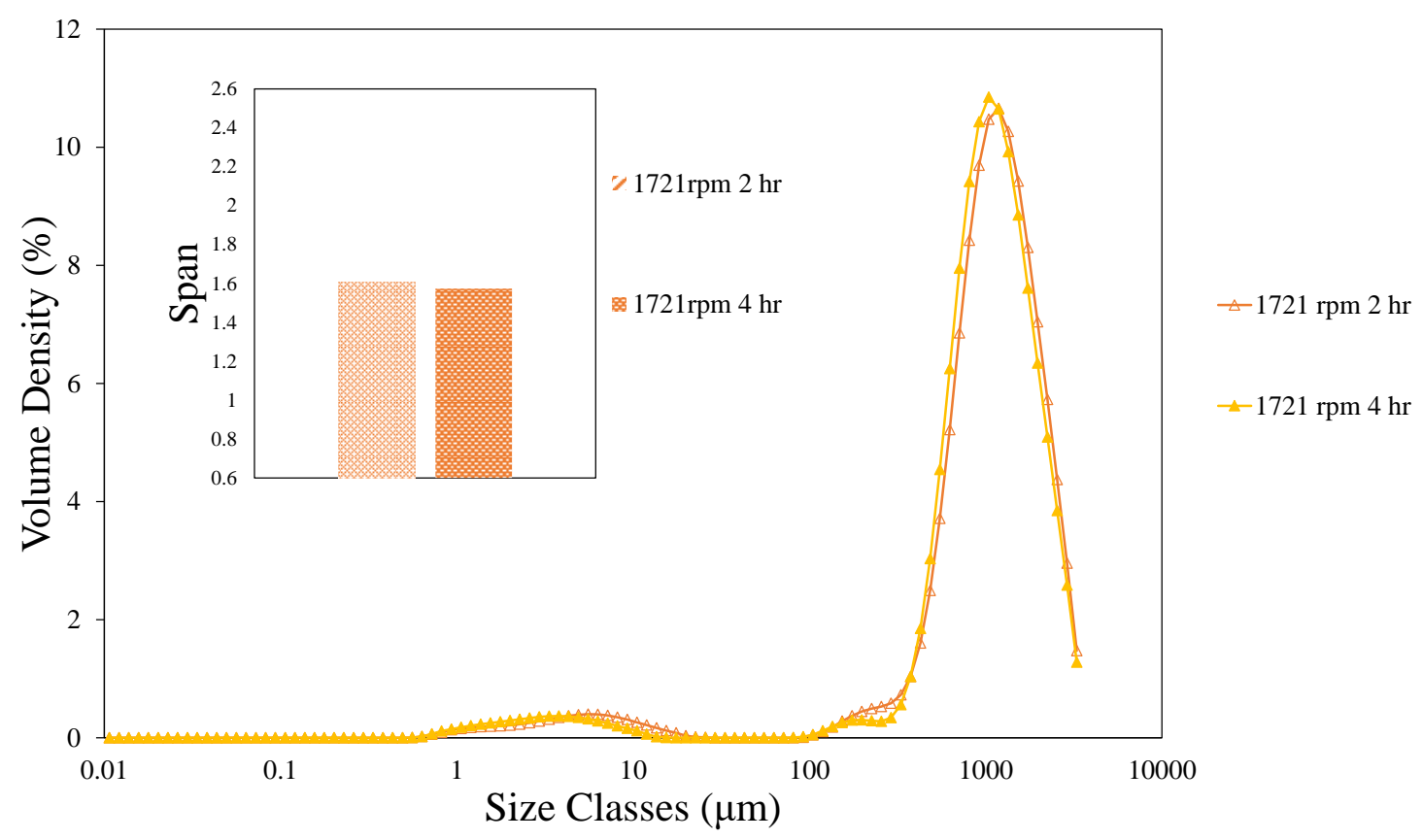

b.

Figure 9. Droplet size distribution for PBT T/3 a. 1485 rpm b. 1721 rpm

\subsection{Mixing time analysis}

The mixing time is related to the circulation time of the tank, which is the time taken for the material to move around the tank. The stirred tank can be divided into two zones: the breakup zone and the coalescence zone. The breakup zone is the region close to the impeller blades. Shear is highest in this region, so the droplets can break here. The newly formed droplet interfaces in this region are also in contact with the particles, so the particles adsorb onto the interface in this zone. The coalescence zone is the areas far from the impeller and close to the tank wall and liquid surface. The shear in this area is low and the droplets are able to maintain contact with each other and coalesce.

The amount of time that droplets spend in the breakup and coalescence zone can be estimated by the mixing time. The mixing time of the configurations with different impellers used to produce the emulsions mentioned in the previous section was measured and reported in this section.

The mixing time results give additional insight to the decreasing trend observed with increased speed. Figure 10 shows the mixing times of the increasing impeller speeds for each impeller. It was observed that the mixing time decreases with increasing speed for all impellers. This confirms that increasing the speed would decrease the residence time of the droplets in the coalescence zone away from the impeller shear zone. Therefore, increasing the speed results in more circulations in the vessel and the droplets take less time to travel to the impeller shear zone and the droplet interface is able to have more contact with the particles. Decreasing the speed then increases the residence time of the droplets in the coalescence zone while also not providing as much shear as the previous speeds. 


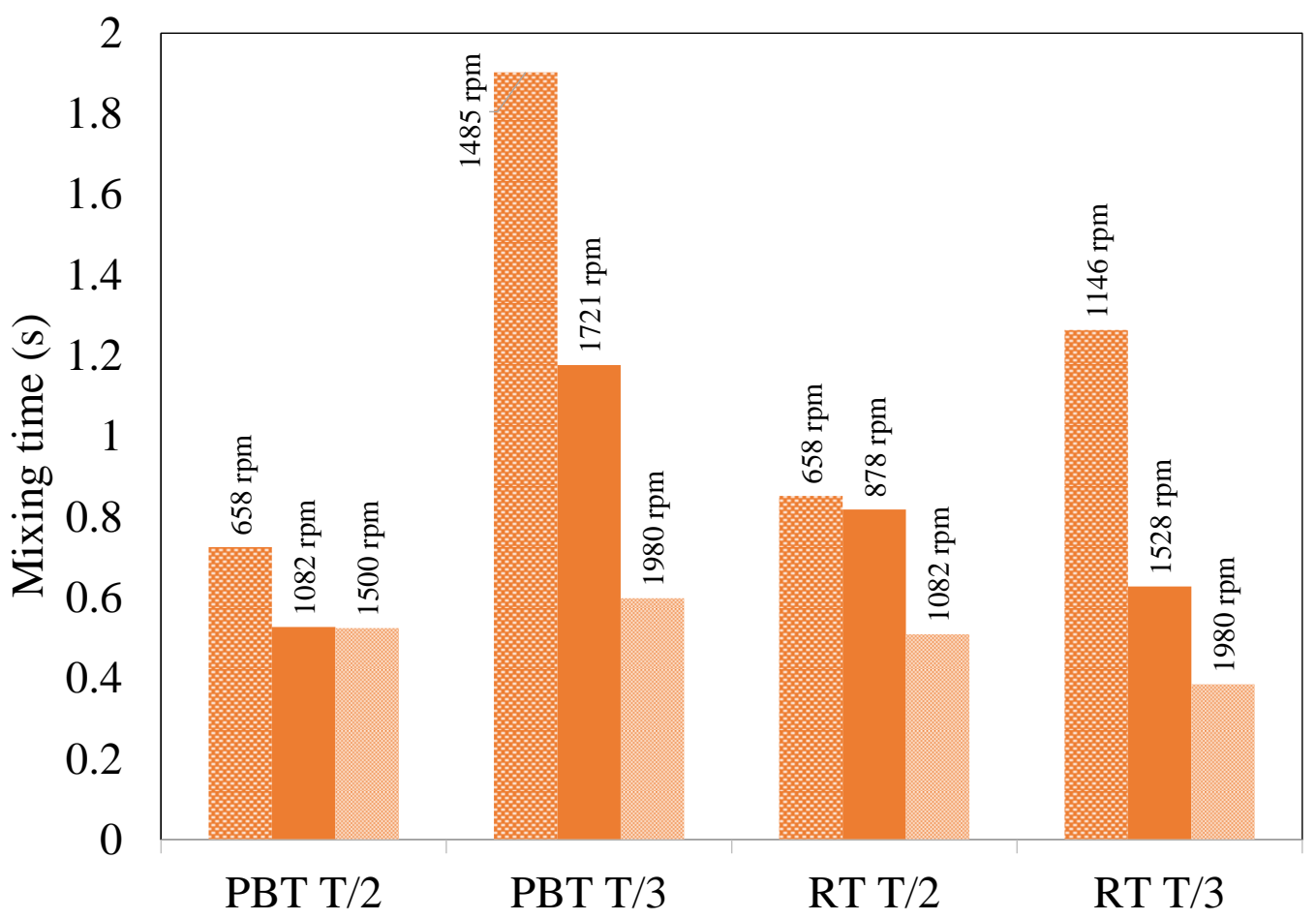

Figure 10. Mixing time of impeller speeds for the four impellers

\section{CONCLUSIONS}

In producing Pickering emulsions, the droplet breakup and coalescence must be considered. The suspension of particles and adsorption of particles onto the droplet interface must also be considered. The objective of this study was to observe the effect of the change of the impeller speed over time on the droplet size of Pickering emulsions. The effect was checked on two different impeller types: PBT impeller and RT impeller at two different sizes: T/2, T/3. The results were then corroborated with a mixing time analysis on all impeller speeds used. The following conclusions were reached:

-For impellers with adequate flow, increased emulsification speed produced smaller droplets. Decreasing the emulsification speed produced bigger droplets.

-Speed hysteresis is observed in the formation of Pickering emulsion droplets.

- To increase the size of an emulsion droplet, it is recommended to use a speed lower than the initial emulsification speed unless there is inadequate flow in the tank as observed for the PBT T/3 impeller.

- The drop sizes at lower speeds are more affected by the change in impeller speed. There is a significant difference between the droplet sizes formed at the low speeds when the speed is decreased from a higher speed and the droplet sizes formed at the low speed when the speed is increased from a lower speed. At intermediate speeds, the droplet sizes formed when the speed is decreased from a higher speed and the droplet sizes formed when the speed is increased from a lower speed are close to each other.

- The PBT is a low shear impeller and coalescence plays a prominent role when the impeller speed is decreased. As a result, bigger droplets are evolved when the impeller speed is decreased than its initial size at the same low speed.

-Increasing the impeller speed decreases the mixing time of the tank. Therefore, the droplets are able to circulate back to the breakup zone more often and spend less time in the coalescence zone. The droplets spend more time in the breakup zone where droplet breakup and particle adsorption can occur. As a result, increasing the impeller speed leads to smaller droplets.

\section{ACKNOWLEDGEMENT}

The authors would like to thank TÜBİTAK (The Scientific and Technological Research Council of Turkey, Project no 116M304) for funding this research.

\section{REFERENCES}

[1] G. Chen, and D. Tao, "An experimental study of stability of oil-water emulsion", Fuel Process Technol, vol. 86, no 5, 499-508, 2005. doi:10.1016/j.fuproc.2004.03.010 [2] S. U. Pickering, "Emulsions", J. Chem. Soc., vol. 91, 2001-2021, 1907. 
[3] B. P. Binks, "Particles as surfactants - Similarities and differences" Curr. Opin. Colloid Interface Sci., vol 7, , 2141, 2002. http://doi.org/10.1016/S1359-0294(02)00008-0

[4] B. P. Binks, and S. O. Lumsdon, "Influence of particle wettability on the type and stability of surfactant-free emulsions", Langmuir, vol. 16, no 23, 8622-8631, 2000. http://doi.org/10.1021/la000189s

[5] B. P. Binks, and S. O. Lumsdon, "Pickering emulsions stabilized by monodisperse latex particles: Effects of particle size", Langmuir, vol. 17, no 15, 4540-4547, 2001. http://doi.org/10.1021/la0103822

[6] R. Aveyard, B. P. Binks and J. H. Clint, "Emulsions stabilised solely by colloidal particles", Adv. Colloid Interface Sci., vol. 100-102(SUPPL.), 503-546, 2003. http://doi.org/10.1016/S0001-8686(02)00069-6

[7] Ė. Tsabet, and L. Fradette, "Effect of the properties of oil, particles, and water on the production of Pickering emulsions", Chem. Eng. Res. and Des., vol. 97, no 1, 9-17, 2015. http://doi.org/10.1016/j.cherd.2015.02.016

[8] S. Arditty, C. P. Whitby, B. P. Binks, V. Schmitt, and F. Leal-Calderon, "Some general features of limited coalescence in solid-stabilized emulsions", European Physical Journal E., vol. 11, no 3, 273-281, 2003. http://doi.org/10.1140/epje/i2003-10018-6

[9] B. Madivala, S. Vandebril, J. Fransaer, and J. Vermant, "Exploiting particle shape in solid stabilized emulsions", Soft Matter, vol. 5, no 8, 1717-1727, 2009. doi:10.1039/b816680c

[10] R. Hemrajani, and G. Tatterson, "Mechanically Stirred
Vessels", Handbook of Industrial Mixing: Science and Practice New Jersey, Wiley and Sons, 2004. http://doi.org/10.1002/0471451452.ch6

[11] Wichterle, K. (1995). Drop breakup by impellers. Chemical Engineering Science, 50(22), 3581-3586. http://doi.org/10.1016/0009-2509(95)00208-M

[12] A. H. P. Skelland and J. S. Kanel, "Minimum Impeller Speeds for Complete Dispersion of Non-Newtonian LiquidLiquid Systems in Baffled Vessels", Ind. Eng. Chem. Res., vol. 29, no 7, 1300-1306, 1990. http://doi.org/10.1021/ie00103a032

[13] S. Bhattacharya, D. Hebert, and S. M. Kresta, "Air entrainment in baffled stirred tanks", Chem. Eng. Res. Des., vol. 85, no 5A, 654-664, 2007. http://doi.org/10.1205/cherd06184

[14] A. Rawle, , "Basic principles of particle size analysis", vol. 86, no $2, \quad 52-65, \quad 2003$. http://doi.org/10.1016/j.apgeochem.2015.02.008

[15] F. Cabaret, S. Bonnot, L. Fradette and P. A. Tanguy, "Mixing Time Analysis Using Colorimetric Methods and Image Processing", Ind. Eng. Chem. Res., vol. 46, no 14, 5032-5042, 2007. http://doi.org/10.1021/ie0613265

[16] L. I. Tolosa, A. Forgiarini, P. Moreno, and J. L. Salager, J. L. (2006). "Combined effects of formulation and stirring on emulsion drop size in the vicinity of three-phase behavior of surfactant-oil water systems", Ind. Eng. Chem. Res., vol. 45, no $11, \quad 3810-3814, \quad 2006$. http://doi.org/10.1021/ie060102j 